\title{
Correlation of Body Condition Score (BCS) to Limousin Cattle Reproduction Status in Purwantoro District, Wonogiri Regency
}

\author{
Ilham Fandi Achmad ${ }^{1}$, Engkus Ainul Yakin ${ }^{2}$, Ludfia Windyasmara ${ }^{2}$ \\ ${ }^{1}$ Department of Maritime, Fisheries and Animal Husbandry, Wonogiri Regency \\ ${ }^{2}$ Program Study of Animal Science, Agriculture Faculty, \\ Universitas Veteran Bangun Nusantara \\ Coresponding author : windyasmaraludfia@gmail.com
}

\begin{abstract}
This study aims to determine the correlation between the Body Condition Score on the reproductive status of limousine cattle in Purwantoro District, Wonogiri Regency. The research was conducted in 6 villages, namely Sumber Galih Village, Gondang Village, Joho Village, Kenteng Village, Purwantoro Village and Miricinde Village in Purwantoro District, Wonogiri Regency. Materials in the study were female limousine cows aged 2-4 years (productive age). Methods of data collection were carried out by conducting observations, direct interviews with breeders, and recording reproduction data from predetermined samples. Observations were made to assess the Body Condition Score (BCS). Interviews and reproduction data recording were carried out to assess reproduction views which included Service Per Conseption (S/C), Conception Rate (CR) scores or conception rates. The data analysis technique used is the t-test difference test (SPSS). The results showed that limousine cows with high HCS had low S/C values and high CR values, while limousine cows with low HCS had high $\mathrm{S} / \mathrm{C}$ values and low CR values, so there was a correlation between HCS and reproductive status, namely the higher BCS gets better reproductive status.
\end{abstract}

Keywords: Conception rate, Limousine cow, Service per conseption, Body condition score

\section{Introduction}

The body condition score is a method for assessing the body condition of livestock both visually and by touching the body fat deposits under the skin around the base of the tail, spine and hips, then it can be divided into three categories, namely thin, medium and obese. The Body Condition Score (BCS) is used to estimate nutritional status, determine the reproductive status of cows, assess the health status of individual livestock and establish the condition of the livestock during routine livestock management. The Body Condition Score (BCS) has proven to be an important practical tool in assessing the body condition of livestock because BCS is the best simple indicator of available fat reserves that can be used by livestock in any period (Susilorini et al., 2007). The Body Condition Score (BCS) has a relationship with livestock 
reproduction, such as fertility, pregnancy, birth, lactation, all of which will affect the reproductive system.

Factors that can reflect the reproductive performance of cattle include the estrous cycle, duration of pregnancy, first lust after birth, first marriage after birth, free time (days open), service per conception, calving interval and assessment of Body Condition Score (BCS). (Santosa et al., 2009).

Purwantoro sub-district is an area with a population of 3,000 cows (Poskeswan, Purwantoro sub-district). Most of the population are limousine cows because limousine cows are cross-breed cows with a very fast body growth and high selling prices. This population is the third largest in Wonogiri Regency. This is because there are still many agricultural lands in Purwantoro District. However, during the dry season, cattle breeders have difficulty finding feed. They usually only feed dry damen to their livestock. Whereas a good feed composition is a mixture of dry and wet feed such as leaves and grass. This limitation will certainly affect the quality score of their livestock body condition.

From these problems, researchers are interested in researching the correlation between Body Condition Score (BCS) on the reproductive status of limousine cows in Purwantoro District. This research is expected to be used as a reference in order to increase cattle production in Purwantoro District. If the results of the research show that there is a correlation between the Body Condition Score (BCS) on reproductive status, it is hoped that the livestock office together with local breeders are expected to be able to create alternative feeds during the dry season. Because livestock feed intake is the main determining factor for BCS If the results of the study show that there is no correlation between the Body Condition Score (BCS) on reproductive status, this study is expected to be able to provide information for calculating BCS and reproductive status from the indicators.

\section{Materials and Methods}

The research was carried out in 6 villages, namely Sumber Galih Village, Gondang Village, Joho Village, Kenteng Village, Purwantoro Village and Miricinde Village in Purwantoro District, Wonogiri Regency.

The materials in this study were female limousine cows aged 2-4 years (productive age). From the six villages, 36 female limousine cows were taken whose Body Condition Score (BCS) represented high and low. The samples representing cows with high SKT were 19 and 17 cows with low BCS.

Methods of data collection were carried out by conducting observations, direct interviews with breeders, and recording reproduction data from predetermined samples. Observations were made to assess the Body Condition Score (BCS), namely by looking at the number of ribs that were shadowing behind the skin and touching the spine. Interviews and reproduction data recording were carried out to assess reproduction views which included Service Per Conseption (S/C), Conception Rate (CR) scores or conception rates.

The data analysis technique used is the t-test difference test (SPSS). Different test is used to determine whether two unrelated samples have different means (Ghozali, 2005). 


\section{Results and Discussion}

\section{A. Population Data}

Limousin cattle are cattle favored by local breeders in Purwantoro District, Wonogiri Regency. This is because this breed of cattle is growing rapidly so that it benefits breeders according to data on the population of cows in Purwantoro District (Puskeswan Kec. Purwantoro), the total number of limousine cows is 1,400, consisting of 1,120 cows, while 600 cows are productive cows.

Table 1. Data on female cattle population in Purwantoro district, Wonogiri regency

\begin{tabular}{clc}
\hline No & \multicolumn{1}{c}{ Type of Cow } & Amount (head) \\
\hline 1 & Limousin & 1,400 \\
2 & Simental & 1,200 \\
3 & PO, Brahman, Angus & 400 \\
\hline \multicolumn{2}{c}{ Total } & 3,000 \\
\hline
\end{tabular}

The source of food in Purwantoro District comes from agricultural waste, namely rice and green plants such as leaves and grass. However, due to the longer dry season, local breeders have difficulty getting green plants for their livestock. Breeders only provide dry damen. This certainly affects the body condition score of the livestock. Cows with good body condition (BCS approximately 3.0 or more), then the estrus cycle after giving birth is shorter than cows that have low BCS $(<3.0)$ (Adiarto, 2012). It can be interpreted that the shorter the estrus cycle in livestock, the better (fertile). The estrus cycle is the interval at which the next estrus begins, which is a process stimulated by the hormone estrogen. The average cycle of estrus in cattle is 21 days (18-24 days) with a duration of 15 hours. Researchers took data from a sample of 36 limousine cows in Purwantoro District to determine whether there was a correlation between BCS and the reproductive status of cows. Where the reproduction status can be calculated with the indicators Service Per Conception (S / C) and Conception Rate (CR).

\section{B. Body Condition Score (BCS)}

The body condition score is the value of the cow's body condition which shows the level of thinness to obesity which can describe the height and the level of the pile of fat tissue in certain body parts as a form of energy reserves that will be dismantled at any time if needed (Adiarto, 2012). From the limousine cattle population data in Table 2, it has been observed that the body condition score of cows aged 2-6 years (productive age) has been carried out by observing the ribs and touching the spine. The Body Condition Score (BCS) taken as a sample ranged from 2-3 of the total population of 600 productive females. Then a sample of 36 were taken. The score for body condition 2 was 17 heads and score for body condition 3 was 19. From the data table 2 also shows that the average results of Artificial Insemination (AI) in cows with high BCS were more successful (+) than cows with low BCS. 
Table 2.List of low BCS Limousin cattle ownership

\begin{tabular}{cllcc}
\hline No & \multicolumn{1}{c}{ Name } & \multicolumn{1}{c}{ Location } & BCS & Result \\
\hline 1 & Bejo & Sumbergalih & 2 & + \\
2 & Jaiman 2 & Sumbergalih & 2 & - \\
3 & Paidi 2 & Sumbergalih & 2 & + \\
4 & Satiman & Sumbergalih & 2 & - \\
5 & Suratnopojok & Gondang & 2 & - \\
6 & Sepi 1 & Gondang & 2 & + \\
7 & Kirankruwet & Joho & 2 & + \\
8 & Paimankasihan & Joho & 2 & - \\
9 & Katnojangglengan & Kenteng & 2 & + \\
10 & Samidijaten & Kenteng & 2 & - \\
11 & Kardipulutan & Kenteng & 2 & + \\
12 & Konthol & Purwantoro & 2 & + \\
13 & Parno 1 & Purwantoro & 2 & + \\
14 & Yatnojaten & Miricinde & 2 & - \\
15 & Yatmojaten & Miricinde & 2 & + \\
16 & Novijorong & Miricinde & 2 & - \\
17 & Martomario & Miricinde & 2 & - \\
\hline
\end{tabular}

Table 3.List of high BCS Limousin cattle ownership

\begin{tabular}{cllcc}
\hline No & \multicolumn{1}{c}{ Name } & Location & BCS & Result \\
\hline 1 & Kasidi & Sumbergalih & 3 & + \\
2 & Nanisalam & Sumbergalih & 3 & + \\
3 & Slamet & Gondang & 3 & + \\
4 & Trimin & Gondang & 3 & - \\
5 & Tarno1 & Gondang & 3 & + \\
6 & Kusnoklepu & Gondang & 3 & + \\
7 & Sukadi 1 & Joho & 3 & - \\
8 & Sular2 & Joho & 3 & + \\
9 & Riyantojoho & Joho & 3 & + \\
10 & Nartosentot & Joho & 3 & + \\
11 & Tarnijangglengan & Kenteng & 3 & + \\
12 & Warnojaitkepuh & Kenteng & 3 & + \\
13 & Kasimbelikbibis & Kenteng & 3 & + \\
14 & Merakihtirisan & Purwantoro & 3 & + \\
15 & Siran 2 & Purwantoro & 3 & + \\
16 & Joyotirisan & Purwantoro & 3 & + \\
17 & Khalis 1 & Purwantoro & 3 & + \\
18 & Kemi 1 & Miricinde & 3 & + \\
19 & Sukiyojoronglor & Miricinde & 3 & + \\
\hline
\end{tabular}

The success of artificial mating (AI) is determined by four factors, namely healthy cows, the right time, semen quality and inseminator experience. In general, if these four factors are fulfilled, pregnancy will be successful with no more than two marriages 
(Makin, 2011). From the results of the research data, repeated mating was more experienced by cows with low BCS. Supported by the results, in general, cows with low BCS who mate repeatedly are not given forage feed and are not given supporting vitamins. This means that it is likely that due to low BCS cows are susceptible to reproductive disorders. Just as BCS affects puberty. Puberty is the time the reproductive cycle begins. For all species there are critical requirements regarding body size, the body must reach a certain size in order for puberty to be initiated. If the requirements of this case are not fulfilled due to lack of nutrition, puberty will be delayed (Fibrianto, 2010).

\section{Service Per Conception (S/C)}

Service Per Conception (S/C) is a number that indicates the number of times mating or artificial insemination required by livestock to produce pregnancy. The normal (S/C) values range from 1.6 to 2 . The lower the value $(\mathrm{S} / \mathrm{C})$ the higher the female fertility rate in a group. Conversely, the higher the value (S/C), the lower the female fertility value in the group (Afiati et al., 2013). From Table 4, the results of the t-test on Service Per Conception (S/C) show that the mean S/C value in cows with high BCS is smaller (1.22) than the S/C value in cows with low BCS $(2,5)$. This means that cows with high $\mathrm{BCS}$ are more fertile than cows with low BCS.

Table 4. Sample t-test results of service per conception (S/C)

\begin{tabular}{clcc}
\hline No & \multicolumn{1}{c}{ District } & Low BCS & High BCS \\
\hline 1 & Sumbergalih & 2 & 1 \\
2 & Gondang & 2 & 1.67 \\
3 & Joho & 2 & 1.67 \\
4 & Kenteng & 2 & 1 \\
5 & Purwantoro & 1 & 1 \\
6 & Miricinde & 6 & 1 \\
\hline & Average & $\mathbf{2 . 5}^{\mathbf{b}}$ & $\mathbf{1 . 2 2}^{\mathbf{a}}$ \\
\hline
\end{tabular}

${ }^{\mathrm{a}, \mathrm{b}}$ Superscript on the same row shows different significant $(\mathrm{P}<0,05)$

The cause of the high S/C rate is generally due to: (1) the farmer detects when he is in heat or is late in reporting his cows' lust to the inseminator, (2) there is an abnormality in the reproductive organs of the mother cow, (3) inseminator is less skilled, (4) insemination service facilities limited, and (5) less smooth transportation. In this case, the high $\mathrm{S} / \mathrm{C}$ value is more due to abnormalities in the reproductive organs of the mother cow. This is because low BCS makes cows susceptible to disease. The researcher did not find the causes for points 1, 3, 4 and 5 because in Purwantoro subdistrict the breeders were already aware as a sign of lust so they immediately contacted the IB officer. Meanwhile, for transportation and communication in the Purwantoro District area, the Artificial Insemination (AI) officers have been equipped with skills through education and training as well as the adequate number of officers for the region. 


\section{Conception Rate (CR)}

The conception rate $(\mathrm{CR})$ is the number of cattle that are pregnant after getting AI. A good CR rate reaches $60-70 \%$. The higher the CR percent number, the higher the AI success rate. From the CR calculation results in this study, it can be seen that the CR of cows with high BCS shows a higher value than the CR of cows with low SKT. This means that cows with high BCS have a higher AI success rate than cows with low BCS.

Table 5. Sample t-test results of conception rate (\%)

\begin{tabular}{|c|c|c|c|}
\hline No & District & Low BCS & High BCS \\
\hline 1 & Sumbergalih & 50 & 100 \\
\hline 2 & Gondang & 50 & 75 \\
\hline 3 & Joho & 50 & 50 \\
\hline 4 & Kenteng & 66,67 & 100 \\
\hline 5 & Purwantoro & 100 & 100 \\
\hline 6 & Miricinde & 25 & 100 \\
\hline & Average & $56.9^{\mathrm{a}}$ & $87.5^{\mathrm{b}}$ \\
\hline
\end{tabular}

${ }^{\mathrm{a}, \mathrm{b}}$ Superscript on the same row shows different significant $(\mathrm{P}<0,05)$

Fanani et al. (2013) stated that the CR value is determined by male fertility, female fertility, and insemination techniques. From this statement, male fertility has become the responsibility of the Artificial Insemination Center as the provider of frozen semen. Meanwhile, storage methods and insemination techniques are the responsibility of the inseminator. In this case the inseminator has taken at least D3 livestock and AI courses as well as various trainings held by the Department of Maritime, Fisheries and Animal Husbandry, Wonogiri Regency. So the low CR value in cows with low BCS is more due to female fertility factors where female fertility is influenced by BCS.

\section{Conclusion}

The research data, it can be concluded limousine cows with low HCS had high S/C values and low CR values, so there was a correlation between HCS and reproductive status, namely the higher BCS gets better reproductive status.

\section{References}

Adiarto, 2012. Beternak Sapi Perah Ramah Lingkungan. Yogyakarta: Citra Aji Kusuma

Budiawan, A., Ihsan, M. N., and S. Wahjuningsih. 2015. Hubungan Body Condition Score Terhadap Service Per Conception dan Calving Interval Sapi Potong Ongole di Kecamatan Babat Kabupaten Lamongan. Jurnal Ternak Tropika Vol. 16, No.1: 34-40, 2015

Fanani, S., Subagyo, Y.B.P, and Lutojo. 2013. Kinerja Reproduksi Sapi Perah Peranakan Frisian Holstein (PFH) di Kecamatan Pudak, Kabupaten Ponorogo. Jurnal Tropical Animal Husbandry Vol. 2b (1), Januari 2013: 21-27

Fibrianto, Y. H. 2010. Buku Ajar Fisiologi Reproduksi Hewan Ternak Betina. Yogyakarta: CV.Kaliwangi 
Ghozali, I. 2005. Analisi Multivariate dengan Program SPSS. Semarang : Badan Penerbit Universitas Diponegoro

Ismaya, 2014. Bioteknologi Inseminasi Buatan pada Sapi dan Kerbau. Yogyakarta: UGM Press

Makin, M. 2011. Tata Laksana Peternakan Sapi Perah. Yogyakarta: Graha Ilmu

Santosa, K.A., D. Kusuma, and T. Toharmat. 2009. Profil Usaha Peternakan Sapi Perah di Indonesia. Bogor: Pusat Penelitian dan Pengembangan Peternakan Badan Penelitian dan Pengembangan Pertanian

Susilorini, T.E., M.E. Sawitri, and Muharlien. 2007. Budidaya 22 Ternak Potensial. Jakarta: Penebar Swadaya 